Proceedings of the Prehistoric Society 86, 2020, pp. 95-110 (C) The Prehistoric Society 2020. This is an Open Access article, distributed under the terms of the Creative Commons Attribution licence (http:// creativecommons.org/licenses/by/4.0/), which permits unrestricted re-use, distribution, and reproduction in any medium, provided the original work is properly cited.

doi:10.1017/ppr.2020.1 First published online 24 April 2020

\title{
A Multisensory Approach to Rock Art: Exploring Tactile and Visual Dimensions in the Southern Scandinavian Rock Art Tradition
}

\author{
By PETER SKOGLUND ${ }^{1}$, TOMAS PERSSON${ }^{2}$ and ANNA CABAK RÉDEI ${ }^{3}$
}

This paper discusses rock art in southern Scandinavia as a multisensory format, where both sight and touch would have contributed to the comprehension of the images. From a structural semiotic point of view, we suggest that rock art can be construed as an organised set of features, such as visual and tactile elements, organised into heterogeneous unities with dynamic relations between elements that can change over time with respect to how they are experienced. We argue that in order to understand the rock art medium, it is crucial to take into consideration the multisensory interaction between the perceiver and the qualities of the rock art surface. The reason for including tactile elements in our interpretation of the conception of rock art is the way it was created: by hands interacting with tools and rock surfaces, as well as the spontaneous human tendency to explore the physical world through touch. One can identify key features in the images that would arguably facilitate tactile recognition, as well as be better explained from a multisensorial perspective. This includes the position of the images on horizontal outcrops, the moderate size of the images, the application of an orthographic perspective, the use of 'tactile markers' (ie crucial features having a strategic function for understanding images by touch), and the occurrence of incomplete images. A multisensorial perspective on rock art furthermore has semiotic implications. Incomplete images, for example, can be understood as indexical stand-ins for the whole imagined picture, ie as iconic indices. A multisensorial approach to Scandinavian rock art thus allows for new explanations for certain design choices, as well as a new understanding of how the images could relay meaning to a perceiver.

Keywords: multisensory, rock art, southern Scandinavia, tactile images, semiotics

Given its expressive, detailed, and figurative character, the rock art in southern Scandinavia constitutes a unique resource in the studies of North European Bronze Age cultures, where figurative art is otherwise typically confined to smaller metal objects or pottery (Kaul 1998; Palincaş 2010).

\footnotetext{
${ }^{1}$ Peter Skoglund, Department of Cultural Sciences, Linnaeus University, Sweden. Email: peter.m.skoglund@lnu.se

${ }^{2}$ Tomas Persson, Department of Philosophy/Cognitive Science, Lund University, Sweden. Email: tomas.persson@ lucs.lu.se

${ }^{3}$ Anna Cabak Rédei, Centre for Languages and Literature/ Cognitive Semiotics, Lund University, Sweden. Email: anna.cabak_redei@semiotik.lu.se
}

However, in order to understand the rock art format, and how it differs from other visual expressions, it is also crucial to take into consideration the multisensory interaction between the perceiver and the qualities of the rock art surface. In the context of southern Scandinavia, where almost all the rock art is engraved, as opposed to painted, this involves sense organs like sight and touch and features of the rock surface. The latter may include furrows that define the outlines of images, as well as cracks and fissures, and the elevation and incline of the panel. Studying rock art as material traces implies that meaning is not external to the imagery, but intimately related to the practice of making, remodelling, and re-interpreting the images (Jones 2015). 
We argue that much of the engraved rock art in southern Scandinavia was intended to be experienced by people who had close contact with the engravings, ie kneeling down and mobilising different senses when perceiving the images. We will discuss certain design principles, such as the size and position of the engravings, the occurrence of unfinished motifs, and the use of tactile markers and orthographic perspective. We argue that these design choices can be explained logically if the intention was for people to combine sight and touch when perceiving the images. This does not exclude a potential importance of other sense modalities, but these are beyond the scope of this paper.

We will restrict ourselves to cognitive and semiotic perspectives on rock art design and not delve into sociocultural explanations for design choices. Our findings, however, have consequences for determining whether or not rock art was a suitable medium for conveying pictorial narratives (Ranta et al. 2019), and thus this issue will be discussed at the end of the paper. Before proceeding, we will give a brief background to the multisensory approach taken here, discuss the prehistoric use of the rock art panels, and clarify our theoretical considerations.

\section{A MULTISENSORY PERSPECTIVE}

In the last decade, there has been a move in disciplines such as history, anthropology, and archaeology toward a broader understanding of the importance of our varied physical senses and how they operate together in order to evoke sensorial effects, emotions, and feelings (Fahlander \& Kjellström 2010; Skeates 2010; Classen 2012; Day 2013; Hamilakis 2013; Pellini et al. 2015).

The ability to make and understand images is often related exclusively to sight. However, Lopes (1997) highlights studies on the ability of blind people and blindfolded people with sight to perceive images by identifying the outlines of picture elements by touch. Dominic Lopes (1997) cites John M. Kennedy's and J. Lew Silver's (1974) study of rock art documented from different cultures and presented as line drawings, which led them to draw the conclusion that lines used to indicate edges on a surface was a universal phenomenon. Furthering this work, Kennedy (in Lopes 1997: 429) also presented a number of 'raised-line outline drawings of familiar objects and scenes' to a group of congenitally or early blind participants unfamiliar with pictures and to a group of sighted but blindfolded participants. The three groups' results were about the same; there were no significant differences in their recognition abilities (Lopes 1997, 429-30; Kennedy \& Silver 1974).

These results are in line with research in philosophy and cognitive sciences (including cognitive psychology and cognitive semiotics), where the notion of embodied cognition often plays a significant role. In aesthetics, for example, there is an argument that the capacity for perspective drawing does not primarily rely on vision, but rather is acquired by us moving around in our lifeworld, a phenomenological term for the ordinary world that we take for granted (Tilley 2004). Even though humans have similar sense organs, we cannot fully understand perception without relating it to a cultural context. Humans are partly socialised into how we use our senses (Classen 2012).

Archaeologists have often relied on visual documentation techniques to understand rock art, where the material aspects of a three-dimensional rock surface are reduced to a simplified two-dimensional image. This produces images which are then viewed detached from the materiality of the panels (Ljunge 2015), thus subjecting us to a strictly visual perception of the images. Kennedy's study (in Lopes 1997) highlights that rock art in its natural setting - where images are defined by grooves and furrows - has equal potential to be understood not only by sight but also by touch.

Humans use a combination of senses in order to solve problems and to comprehend the world. The idea of ranking senses and treating them separately is a modern Western tradition, which cannot be used as a standard when studying ancient cultures (Skeates 2010). Christopher Tilley (2004) describes two traditions regarding sensory modes: 1) analytic thought, where the various senses (sight, touch, smell, hearing, and taste) are often 'treated separately', and 2) the phenomenological approach, where senses are integrated and corporeally experienced. For the latter, one needs to consider not only the visual aspects of a landscape, but also other sensory aspects of it, eg, smell, touch, and hearing (Tilley 2004). In other words, we need to consider 'the phenomenological implications of synaesthesia: that sensing the world involves a continual intertwining of the various ways in which we perceive it' (Tilley 2004, 28).

An emerging approach in rock art research, which supports a multisensory perspective, is the focus on the materiality of rock art and the actual practice of making rock art. The assumption is that the environment 


\section{P. Skoglund et al. A MULTISENSORY APPROACH TO SOUTHERN SCANDINAVIAN ROCK ART}

triggers or structures the rock art and is sometimes reflected in the design decisions of the rock art makers. It is argued that rock art images cannot be understood by analysing visual documentations alone; the meaning of rock art is intimately related to the materiality of the panel and the wider landscape setting (Tilley 2004; Jones et al. 2011; Ljunge 2015). Several studies have highlighted how motifs are integrated into fissures, cracks, and quartzite veins, demonstrating that the panels are not neutral backgrounds, but the craftsperson making the images was interacting with the character and nature of the outcrop (Jones et al. 2011, Fahlander 2012; 2013; 2018; Ljunge 2015). The panel itself structured the layout and design of the motifs in some cases and the maker must have continuously adapted the activity to the material employed.

In the following section, we will highlight some aspects of the long-term use of rock art panels in southern Scandinavia in order to underline the importance of the tactile sense. While touch may have many functions in relation to rock art (Ouzman 2001), we will focus exclusively on touch as a means of acquiring pictorial meaning from the images.

\section{THE MAKING OF ROCK ART}

Scandinavian rock art is generally located outdoors, and images would have become less visible over time. The majority is pecked, and stands out as light grey when newly created, yet images would have darkened over time and become more difficult to identify by sight. Processes that diminish visibility particularly affect areas that are dominated by gneiss or granite, which include the majority of rock art panels in southern Scandinavia, such as the areas around Tanum, Norrköping, and Enköping in Sweden. Furthermore, growing lichen and mosses would have made it difficult to observe the figures as time passed. Ice, snow and rain affected the panels by breaking off pieces and creating new cracks, also decreasing the visibility of the motifs (Bakkevig 2004).

These processes were dependent on the local environment. Those panels located close to the sea and regularly washed by saltwater would not have been subjected to the growth of lichen and mosses. This might be why, at certain locations such as Alta in northern Scandinavia, people preferred to locate the carvings just at the water's edge (Gjerde 2010). In southern Scandinavia, there is no such straightforward pattern. There are many panels located just at the shoreline, but there is a great variation, and many panels are also located further inland (Ling 2008; 2013; Nimura 2016), where they were likely more affected by the growth of mosses and lichen. At many places in southern Scandinavia, post-glacial shoredisplacement processes changed the environment of individual panels. Due to these processes, motifs made in the Early Bronze Age on panels located just at the shore could end up being several hundred metres from the shore 1000 years later (Ling 2008; 2013; Nimura 2016).

Various techniques were possibly used to increase the visibility in order to overcome these problems. Even though there is no evidence of paint in relation to rock art images (Bengtsson 2002, 272; Hauptman 2002, 184), it is not unlikely that paint might have been applied to increase visibility. However, given that rock art generally is horizontally positioned and exposed to weathering, any such colour would have faded and ultimately disappeared after some time. Re-pecking was another way to increase visibility, since it could make images stand out again as light grey on a darker background. The depth of many images indicate that they were re-pecked on a regular basis (Goldhahn 2012). As stressed by Katherine Hauptman (2002), the low visibility of the carvings made it possible for people to make an active choice in what types of images should be made visible at any specific point in time by re-pecking or using colour. Painting and re-pecking, however, only provide a temporary solution to the problem of visibility. Finally, light conditions do, and did, undoubtedly affect the visibility of the motifs. When the sun was in a favourable position, the engravings would have been relatively easy to identify, while during certain weather conditions, they would have been difficult to see.

The problem of visibility becomes especially crucial in relation to the long-term use of rock art. There are many examples of new images being placed close to, or in relation to, older images. Sometimes images from the Late Bronze Age (1100-500 BC) are positioned close to images made in the Early Bronze Age (1700-1100 BC). The time gap between the making of these closely-related images may be as much as 1000 years (Ling 2008; Rédei et al. 2018). These processes can be studied due to the fact that images in a new style were added to already existing images made in an older style. There are also examples of individual images being updated or remodelled as new details were added to already existing images. For example, 
a ship made in the Early Bronze Age may have been updated by adding new details to the prow in accordance to a new 'style' (Milstreu 2017).

The long-term use of the same panels suggests that during the Bronze Age, rock art panels would have included images with different degrees of visibility. When adding a new image to a panel with older images, or adding new elements to an already existing image, touch would also be helpful in relating new features to older images defined by less visible furrows. Engraved images inherently consist of qualities triggering both sight and touch. The colour contrast between the image and the surrounding panel attracts the eye, while the pecked marks also attract the touch of the fingertips. In this way, touch can be the primary sense, since one can feel motifs that are difficult to see, but not vice versa. Thus, we argue, a multisensory approach can help us understand the long-term use of rock art panels.

\section{A SEMIOTIC APPROACH}

Rock art in southern Scandinavia is characterised by a large quantity of figurative art. The practice of making durable images that depict real world objects, animals, and humans implies that the images were meant to be seen and understood, not only by the craftsperson who made them, but also by other people. In semiotic terms, these images were 'iconic signs' for the objects, animals, and humans existing in the sociocultural context in which they emerged (Peirce 1998; Rédei et al. 2018). What defines these images as iconic signs is that the rock art motif, as well as the mental image that it elicits, is based on a similarity to that which it represents, which can be an imagined or existing thing in the physical world. As an iconic sign, the rock art (the expression of the sign) and the mental image (the content of the sign) produced by the rock art, thus have the same referent. But images can never be purely iconic expressions; they are not exclusively determined by similarity (Peirce 1998). Cultural factors are important for determining what expressions are favoured, which has been thoroughly discussed in cultural semiotics (Rédei 2007; Sonesson 2016). In our case, we assume that iconic signs are also determined by environmental factors, such as the specific conditions of the rock surfaces. Indexical signs are signs that refer to relations between objects or phenomena in the world, in time (as a fossil could do) or in space (as the bread at display in the shopping window of a bakery could do). Due to the figurative nature of southern Scandinavian rock art, we will assume, however, that the dominant semiotic system in this case is indeed iconic. Furthermore, we propose that this includes tactile iconicity, as well as indexicality, which we discuss further below.

In the following sections, we will give examples that are primarily taken from major rock art centres in south and central Sweden such as Tanum, Norrköping, and Enköping, which have been visited by the authors on several occasions. We consider these sites as representative of the rock art tradition in southern Scandinavia dating to $c .1700-200 \mathrm{BC}$ (for a definition of this tradition, see Goldhahn \& Ling 2013).

\section{ROCK ART AND THE TACTILE SENSE}

The term rock art is generally understood as images that are engraved or painted on stones or rock surfaces. A distinction is often made between images that are pecked into the rock, ie petroglyphs, and images that are made by paint, ie pictographs. With very few exceptions, there are virtually no known pictographs in the southern rock art tradition, and nearly all rock art are petroglyphs. While pictographs are dependent on sight in order to be comprehended, petroglyphs can be experienced by sight and/or touch. Together, these senses can complete and complement how they are experienced.

The size of the images impacts the visibility of rock art. Presumably larger motifs are more visible than smaller motifs, and the southern Scandinavian rock art motifs are typically not large. For example, based on a survey of 433 ship images from a study area in northern Bohuslän, Sweden, Johan Ling (2008) concluded that the most common ship image from the Late Bronze Age (1100-500 BC) was 35-45 cm long. The vast majority of the ship images in both the Early and Late Bronze Age were less than $70 \mathrm{~cm}$ long, even though in exceptional cases ships may be as long as $4.5 \mathrm{~m}$ (Ling 2008, 191-7).

The majority of rock art motifs are therefore 'miniatures'. The most common exceptions to this pattern are objects and body parts depicted on a scale of 1:1 (Fig. 1). These only include objects which are smaller in reality, such as metal axes, or parts of the body, such as footprints and occasionally hand images (Skoglund et al. 2017, 294). Larger objects, such as spears and shields, are mostly miniaturised and are only depicted on a scale of 1:1 in exceptional cases. 


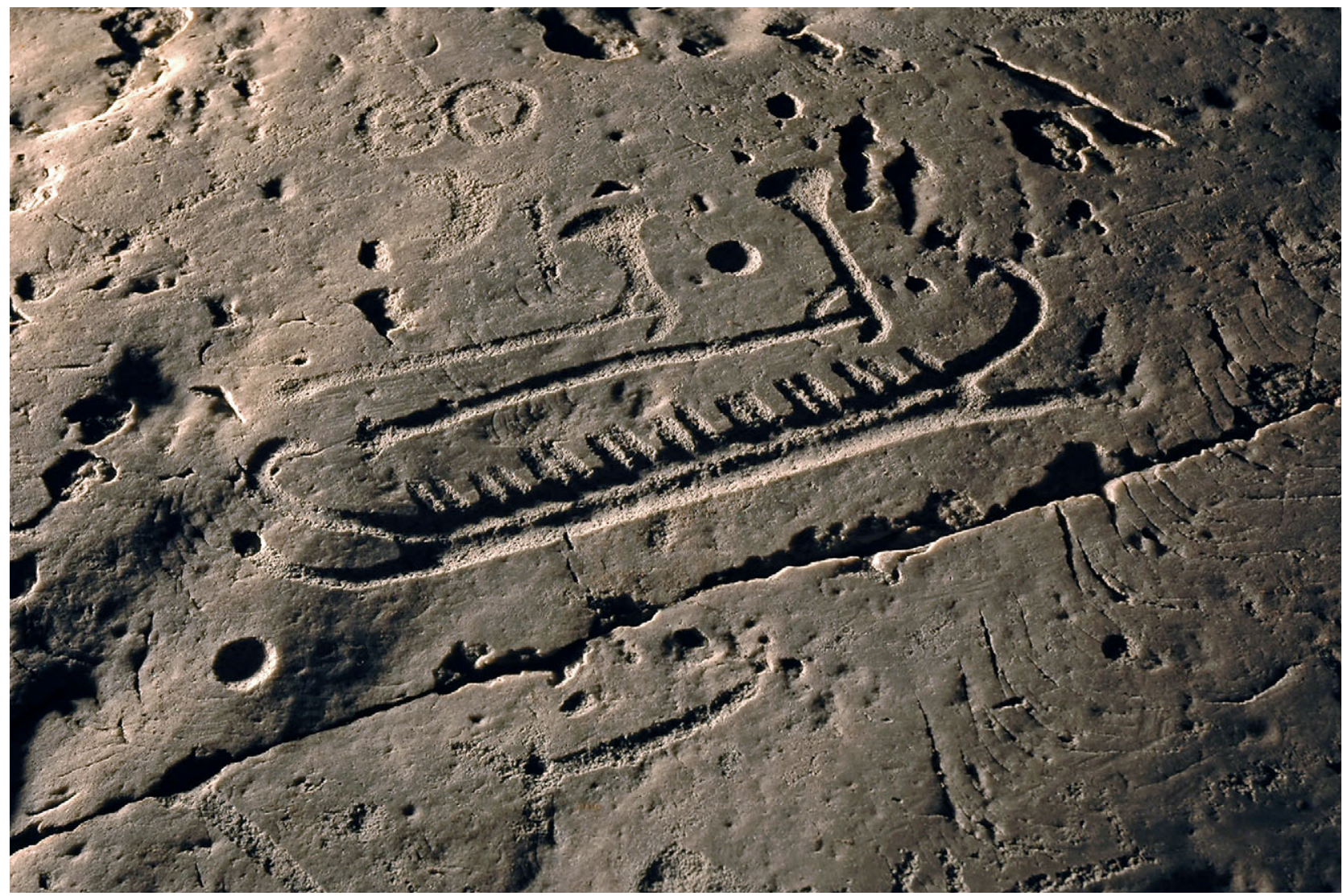

Fig. 1.

Image showing a ship (miniature) and two axes (scale 1:1). Note the turned-in fore and aft stems; these might function as tactile markers to facilitate recognition. Simrislund, Scania, Sweden. (Photo: Catarina Bertilsson. SHFA ID 1837)

This might be yet another circumstance pointing to the importance of using touch on panels with low visibility. Objects that are easily identifiable by their global shape - the whole object - using touch in real life are those that are more likely to be depicted on a natural scale on the panels. In fact, such objects might be more difficult to identify when miniaturised, compared to objects that are never identified in real life by their global shape using touch. That is to say, you can feel the whole shape of a small axe or a hand, eg, in darkness, but you can only feel a part of a long spear or a human body under the same circumstances. While visual priority cannot be excluded, the typical sizes indeed suggest a combination of tactile and visual interpretation (cf Hopkins 2000, 158).

The size of the images means they are not usually visible from a distance but are more suitable for having a good visual overview either from a typical standing height or from a kneeling position on the panels. As the majority of southern Scandinavian rock art panels are found on more or less horizontal outcrops, the natural response is to approach the images closely in order to see them better, which means that you often have to kneel down and possibly support your body with your hands. This manual closeness to the rock surface invites you to use your hands to trace the images. The hollows and depressions recognised by the fingertips provide important pieces of information, adding to what can be detected by sight. The colour contrast between the image and the surrounding panel attracts the eye, while the pecked marks attract the touch of the fingertips. Thus, both visual and tactile features trigger the understanding of the motif as an iconic sign.

There is a noteworthy absence of very large images, which would have been easily visible, but difficult to 


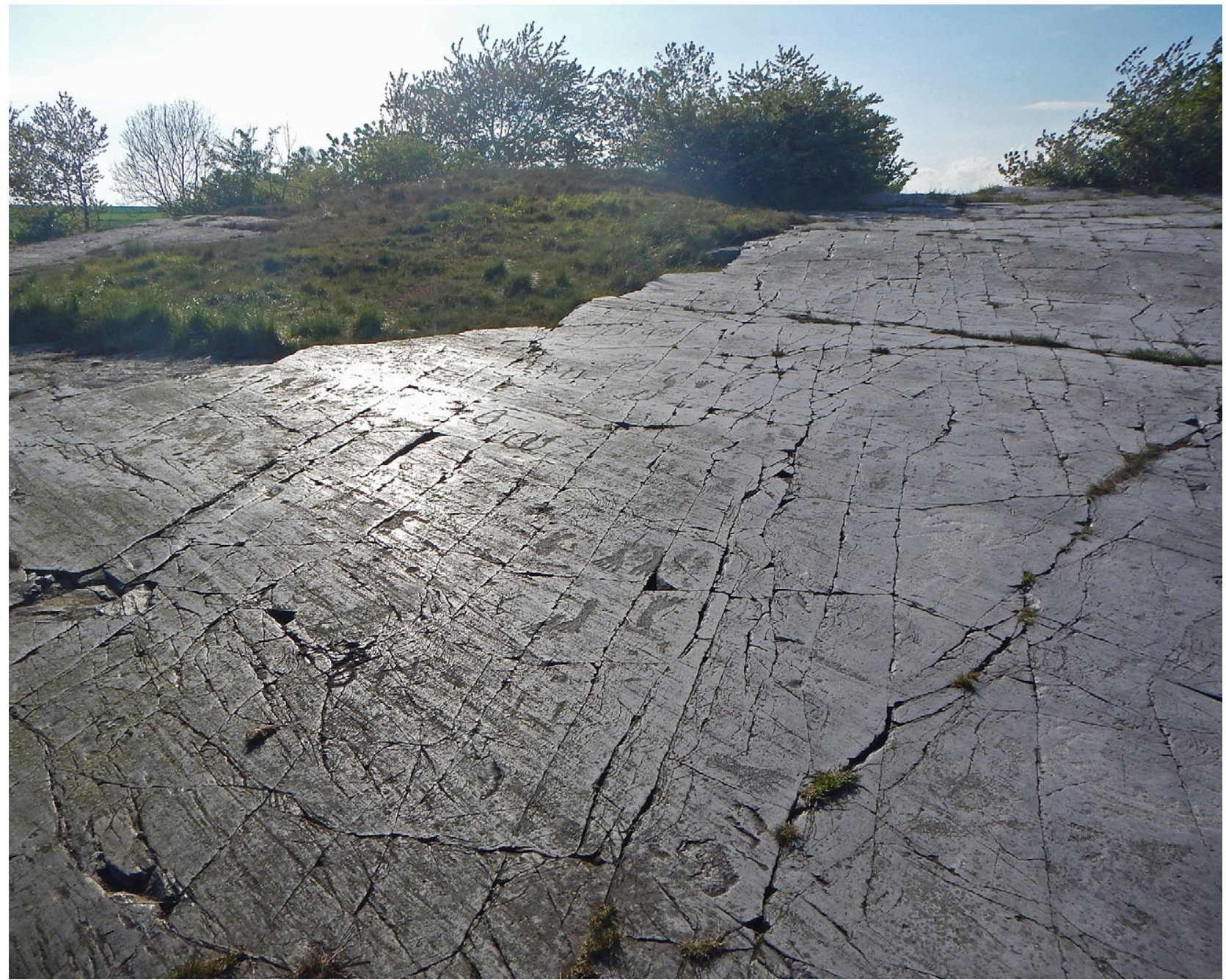

Fig. 2.

Image demonstrating the horizontal character of a rock art panel, facilitating free movement and closer contact with the engravings. Järrestad, Scania, Sweden. (Photo: Peter Skoglund. SHFA ID 11240)

appreciate coherently by touch. To be tactilely effective, images need to be large enough to have sufficiently distinct details, but small enough to retain a coherence that a hand can interpret. To be visually effective, a picture can be very large and still be coherent. The predominance of smaller images suggests that the rock art was not exclusively visual (Fig. 2). Some images were likely designed and positioned in order to be seen from a distance. Lövåsen, at the World Heritage site of Tanum in northern Bohuslän (Tanum Swedish Heritage Agency Database Site No. $323: 1)$, is on an almost vertical outcrop and displays a $2.7 \mathrm{~m}$-long, fully-engraved ship image overlooking what was a sheltered bay in the Bronze Age (Coles 2006; Ling 2008, 136-42). While you cannot see images from afar on horizontal panels, it might be intentional that many of the larger images are on vertical cliffs, where they could have been seen from a distance (Fig. 3). When newly pecked, the ship at Lövåsen must have been visible from an even greater distance by people approaching from the sea. A number of smaller engravings are found both on this vertical cliff and atop the more horizontal section of the cliff (Fig. 4). When reconstructing the Bronze Age landscape, it is clear that the vertical cliff was accessed from the sea, a context in which it would 


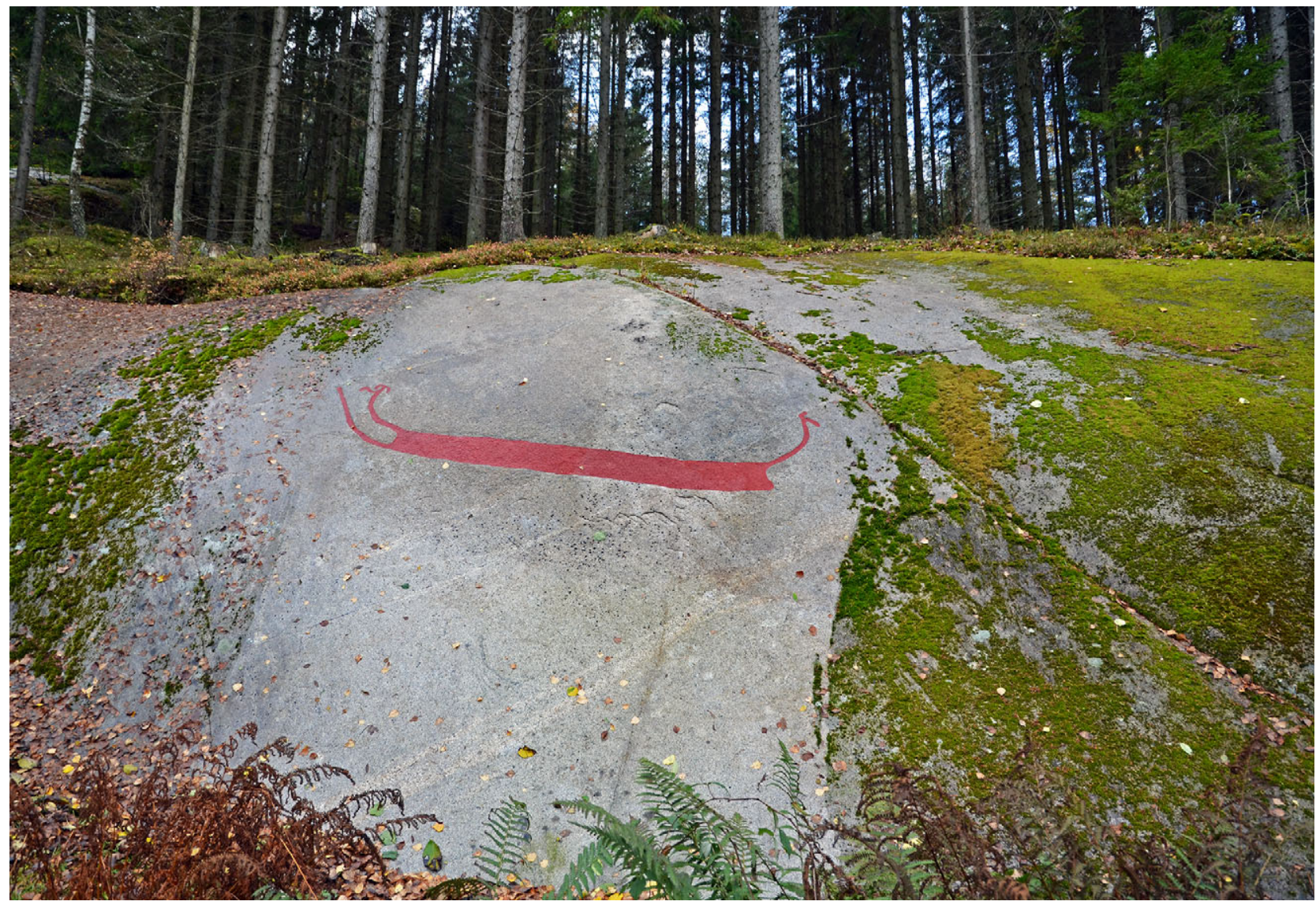

Fig. 3.

A $2.7 \mathrm{~m}$-long ship located on an almost vertical panel. In the Bronze Age, this panel was situated close to and facing the sea. The large size of the image might indicate that it was primarily meant to be seen and the tactile dimensions were less important. Lövåsen, Tanum, Bohulän. Note: antiquarians have applied the paint to increase visibility. (Photo: Catarina Bertilsson. SHFA ID 8718)

be logical to make and experience images in an exclusively visual mode. Where vision is the dominant modality, size could have been used to increase visibility.

Other examples are the $4.2 \mathrm{~m}$-long Brandskog ship, close to Enköping, and the $3.0 \mathrm{~m}$-long ship at Skepplanda, close to the major river Göta Älv, which is on a vertical cliff (Rex Svensson 1982; Skepplanda 20:1). The Brandskog ship is visible from a distance, and both the ship and the crew are depicted with many fine details. There is a small group of larger images in the area, which may represent the final phase of rock art production in that region (Fahlander 2018, 72-6). These examples demonstrate that it was possible for rock art makers to position larger scale images on vertical panels to increase their visibility. However, these are exceptional examples. The majority of images are depicted on a smaller scale on nearly horizontal outcrops (Fig. 4), indicating that these types of images served much more common functions or meanings, and were likely transmitted by both tactile and visual exploration.

\section{THE TACTILE DIMENSION OF ROCK ART IMAGES}

Vision is able to operate on a global scale, incorporating information from various parts of a larger panel, whereas the tactile sense relies on smaller scale information that can only be gained at any given moment by feeling the pecked lines with one's fingertips. Comprehension of images by touch is made possible by the presence of simple, pertinent details which are typical - or even specific - to a thing. In theory, then, we can analyse the character of individual images 


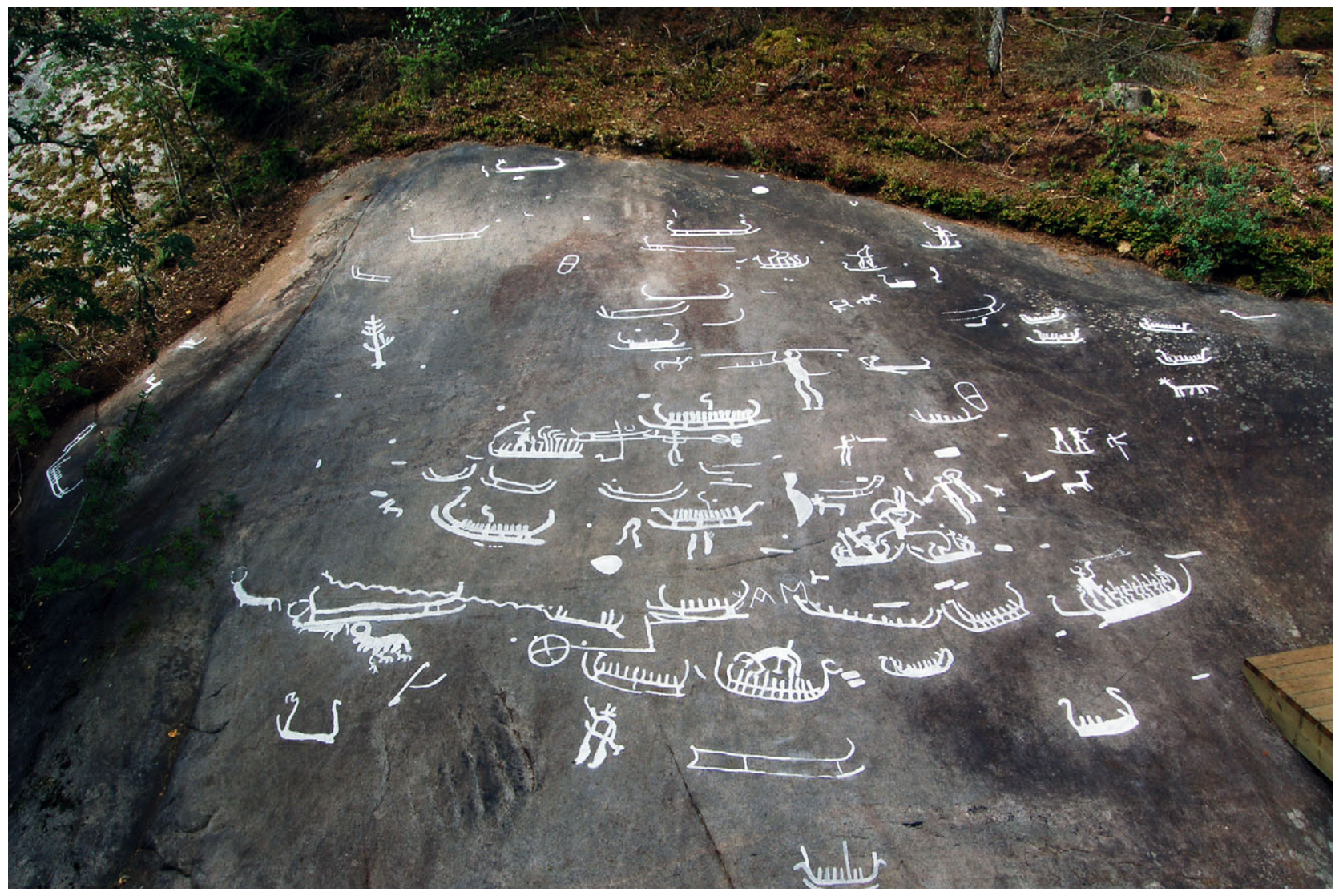

Fig. 4.

These engravings are located on a horizontal panel situated close to the large ship in Fig. 3. They are comparatively small, tactile markers such as ship stems are numerous, and a number of parts-of-whole objects are also present.

These details indicate that they were meant to be comprehended by both sight and touch. Lövåsen, Tanum, Sweden. Note: antiquarians have applied the paint for documentary purposes. (Photo: Tanums Hällristningsmuseum. SHFA ID 1688)

to determine whether they were designed to be interpreted with the tactile sense as well as by vision. In her study of tactile pictures, Yvonne Eriksson (1998) concludes that to make an image identifiable by touch, one should combine a simple shape with exaggerated principal characteristics of the real object. Characteristic features of the object depicted may function as indexical cues for the object as a whole (the iconic sign). Outlines are also important in connection with tactile images due to their essential function of marking edges (Kennedy \& Silver 1974; Lopes 1997).

Although we argue for multisensorial perception of rock art, we do not assume that vision and touch independently can feed the brain with the same information, nor convey identical meanings. There are important differences between purely visual and purely tactile pictorial perception. As Robert Hopkins (2000) points out, while vision can give a global impression of an image, only parts of a shape are available to touch at any given moment, and there is not a given starting point for the exploration of an outline shape. Tactile investigation of an engraving can only lead to a 'tactile belief' regarding a shape; the shape itself is put together mentally piece by piece. The visual shape, in contrast, is not limited in this way. The different interpretative processes involved in the visual and tactile exploration of engraved images have different consequences for the meanings they can convey. In the multisensory case, however, the constraints posed by one modality can be complemented by the other modality, and a coherent 'visual-tactile belief' can be formed.

It is difficult to say whether or not this was important to the rock art producer when creating the images, but some design choices support the idea that 


\section{P. Skoglund et al. A MULTISENSORY APPROACH TO SOUTHERN SCANDINAVIAN ROCK ART}

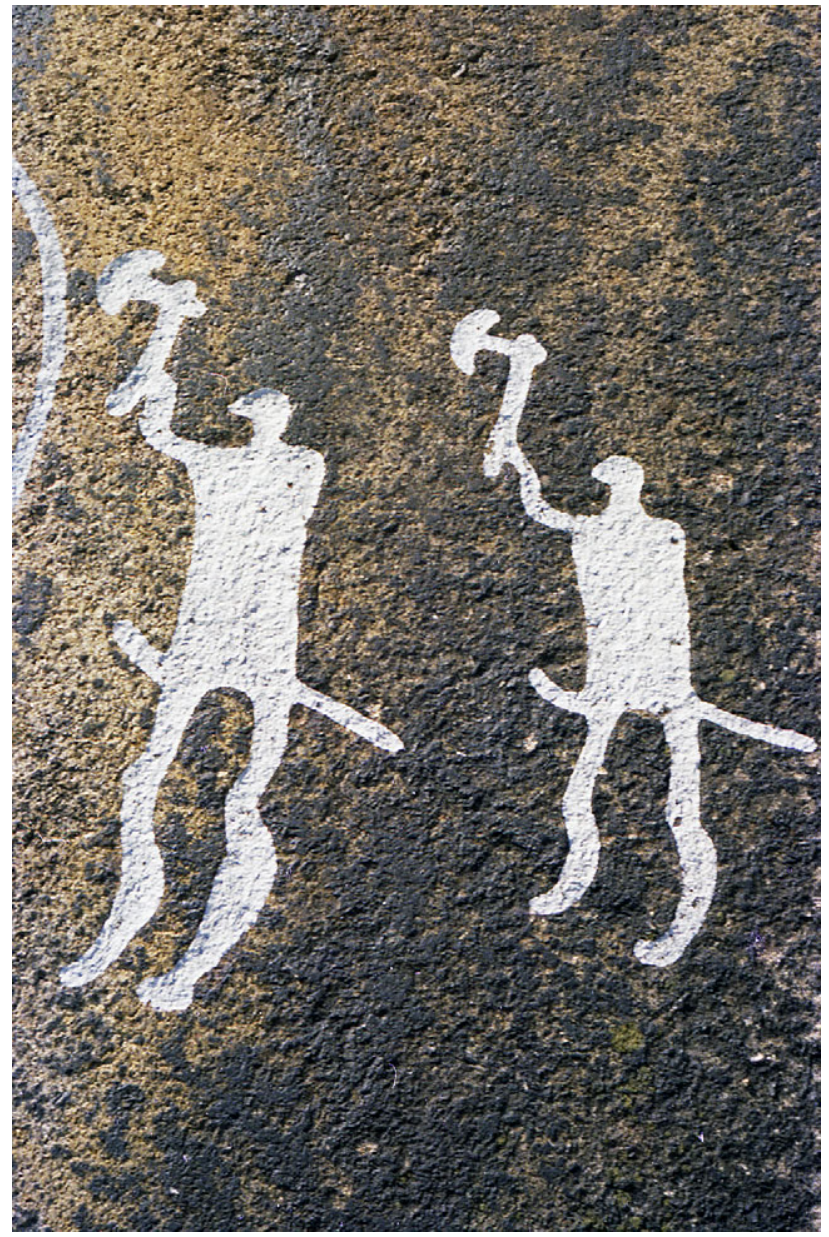

Fig. 5.

Two people with exaggerated calves, examples of possible tactile markers. Fossum, Tanum, Bohuslän. Note: antiquarians have applied the paint for documentary purposes. (Photo: Bertil Almgren. SHFA ID 11609)

multisensorial experience was considered in certain styles of rock art. Some pertinent details seem to support both tactile and visual identification, but this was arguably a cultural development. For example, a recurring feature of human representations in southern Scandinavian rock art is exposed legs and exaggerated calves. Oversized calves stand out as an important element: they are formed of two parallel lines, one straight and one curved. They may relate to contemporary material culture, such as shin guards (Vogt 2006, 79). Alternatively, they may have served to differentiate human legs from other kinds of motifs made out of straight parallel lines (for example ships) (Fig. 5), especially when experienced by touch. Other pertinent features distinguishing human figures (males) from others in southern Scandinavian rock art are the upward-pointing phallus and the downward pointing sheathed sword. Phalluses and weapons, such as spears, are generally exaggerated, which makes sense if they were to be experienced by touch. The common combination of an upward-pointing phallus and a downwardpointing sheathed sword on a single figure makes it easy to recognise this category of men both visually and using touch. One can even infer the direction that the figure is facing, just as with oversize calves.

The ship is the most common rock art motif in the southern Scandinavian tradition. Early Iron Age rock art ships dating to 500-200 BC demonstrate great accuracy in detail and are comparable to the preserved wooden canoe from Hjortspring in Denmark (Crumlin-Pedersen \& Trakadas 2003). It seems reasonable that earlier ship images also represented real designs of contemporary wooden canoes. They have details probably drawn from real observations, but also have exaggerated features that would have aided in their visual and tactile recognition. This is true of the characteristic raised prows at one or both ends of the vessel. Rock art ships from the earlier Bronze Age, for example, have both prows bent backward into a semi-circular shape, sometimes almost hitting the hull (Fig. 1). Perhaps the prow - just as calves, phalluses, and sheathed swords in human images - was a crucial detail that helped identify the image when visibility was suboptimal.

Depictions of prows, which changed significantly over time, have played a key role in the development of a chronology for Scandinavian ship images (Kaul 1998; Ling 2008). For Bronze Age people as well, it would have been possible to distinguish contemporary boats from boats made in an older style. Interestingly, on some panels, older boats were updated in later periods by adding details to the prows, making them look more like contemporary boat types (Milstreu 2017). Such updating is evidence that people discovered older images but it could also have served another purpose. When relying on touch and not sight, accuracy and updating details would have been important, because lines that deviate from an expected pattern can cause confusion. Vision can take in a whole scene and let the totality scaffold the parts, whereas with touch, one typically has to piece together the interpretation of the image piece-by-piece (and serially). This is why touch and sight are so powerful together: vision keeps track of the whole, while haptics explore the parts. 


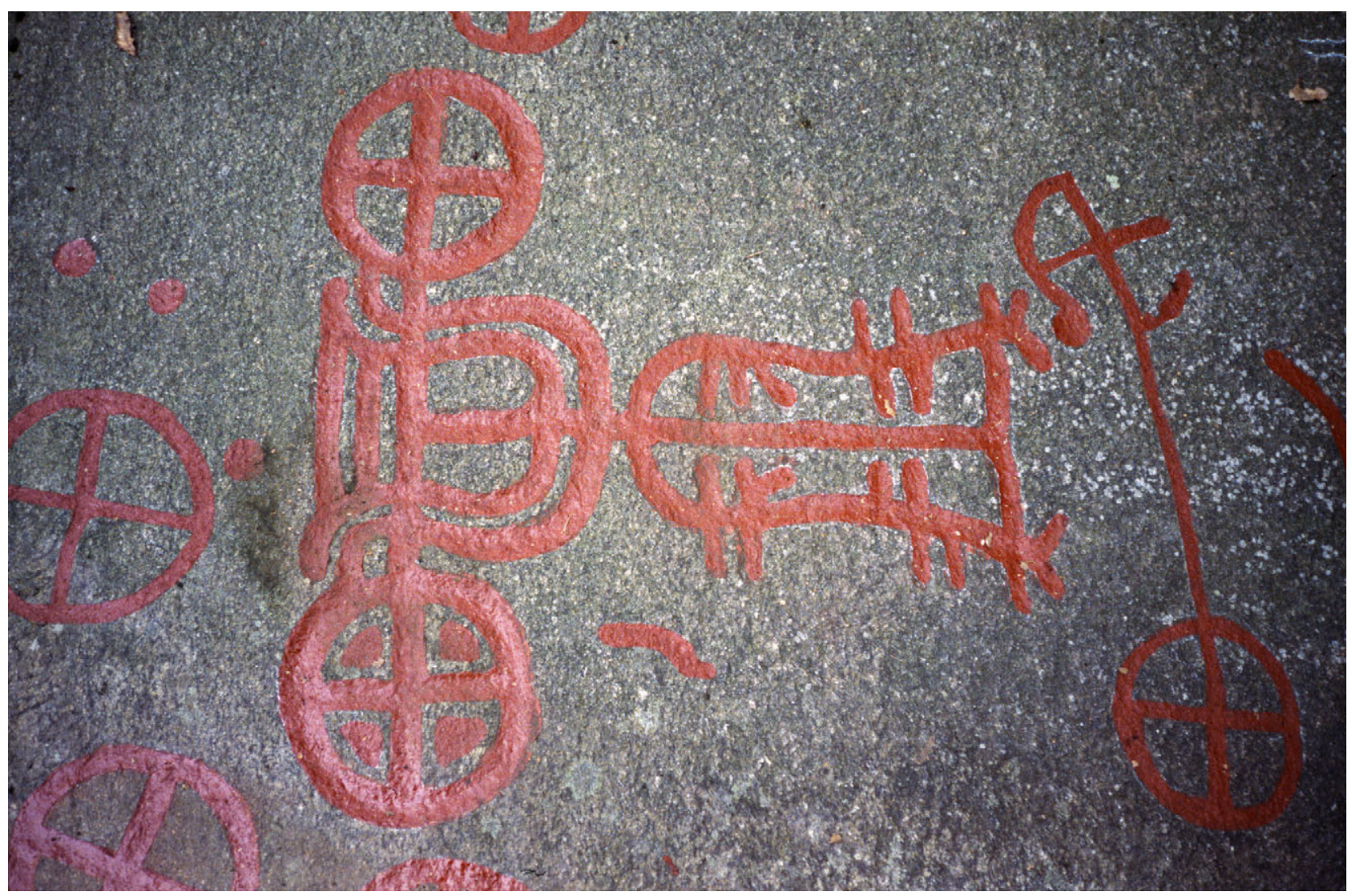

Fig. 6.

A wagon or chariot displayed in an orthographic perspective, which would have facilitated tactile recognition. Frännarp, Scania, Sweden. Note: antiquarians have applied the paint to increase visibility.

(Photo: Sven-Gunnar Broström. SHFA ID 14596)

Orthographic perspective, ie when one object is depicted from several right-angle positions, relays an account of the structure and function of the object. It is a technique often used to illustrate objects in tactile pictures made for blind people, because it maximises the information relayed about the object and makes it more easily identifiable. Studies of the drawing abilities of blind people also show that there seems to be a preference for making drawings using this technique (Eriksson 1998, 81). Orthographic perspective is often used with wagons and chariots in southern Scandinavian rock art, where the body of a wagon may be displayed from above, while the wheels and the draught animals are displayed from the side (Fig. 6). The focus is on maximum information, rather than visual realism, which would arguably be an advantage when using touch during the process of interpretation. Also, touching a 'splayed-out' object is more like exploring a $3 \mathrm{D}$ object than touching a single perspective of the object. While this is true to some extent when visually inspecting an object, we suggest with single perspectives that vision fares much better than haptics.

Another feature of this rock art, which is atypical for visual representations, is that sometimes humans, animals, or objects are 'unfinished', lacking details that one might expect in a visual representation (Horn \& Potter 2016). A recurrent example is pairs of legs that are not attached to a human body (Marstrander 1963, 213). In southern Scandinavian rock art, it seems as if the body could be represented as a totality with all parts of the body or be signified by only part of the body, for example a pair of legs. Legs may have been an indexical cue for the whole (human) within a specific pictorial culture (Yates 1993; Karlsson 2005; Skogstrand 2005; Horn \& Potter 2018). From a tactile 


\section{P. Skoglund et al. A MULTISENSORY APPROACH TO SOUTHERN SCANDINAVIAN ROCK ART}

perspective, it might even be more effective to omit as much as possible when creating an image. If the first thing you encountered were two legs, your recognition of a human would have been much quicker than if you first encountered a head, from which you would have had to trace the rest of the body to interpret it as a human.

Indexical signs indicate, as already mentioned, relations between objects in the world (Sonesson 1994; Peirce 1998; Rédei et al. 2019). For example, footprints left in the sand indicate that somebody walked there at some point in time (contiguity). An indexical sign can also stand for relations between parts and wholes (factorality). For an observer making an inference, a human, being exclusively bipedal, is well indicated by a pair of legs. Indexical inferences of this kind also involve elements of icons (Peirce 1998). Icons are signs which depend on their similarity to the objects they refer to in the eyes of the observer. In the case of the oversized calves, the observer would first need to perceive (visually and/or by touch) the similarities between the pair of human legs and then infer that they are two legs and, by way of inference, that they are part of an imagined human body (and not of an animal body, which would have more than two, and very different types of, legs). The evoked content (mental image) of the sign is a human being (the whole) and not two isolated legs. Thus, it is a meaning unit in flux, oscillating in perception between indexical and iconic understandings.

Inferring wholes from parts, however, requires experience and is culturally specific. Kennedy and Ross (1975) tested the ability of the Songe - a group of people living in a village in Papua New Guinea who lacked experience with pictorial art - to recognise what certain images represented. They found that a disjointed part of a whole was difficult to identify; in this case, an outline drawing of an arm was not recognised as an arm. If a part cannot be interpreted as a part in the first place, it will not invoke inference of the whole to which it belongs. Likewise, wholes feed back to their parts. We would argue in this case that the arm is an indexical element in the iconic drawing; as it was portrayed in singular and not in a pair, it did not meet the expectations of a typical body and was thus more difficult to recognise. In a tactile context, however, this might not have had such a negative effect, as global shapes are never given to perception in a tactile mode, where information needs to be gathered step-by-step as one moves, for example, the finger tip over a surface. Instead, the interpretative process must be much more active than in a visual mode. In a purely visual image, the absence of an expected shape, such as the owner of the arm, could perhaps hinder interpretation to a larger degree than in an engraved picture, where one arm would give enough information for the 'toucher' to infer that one arm likely is an indexical sign for a pair of arms.

The unfinished character of some rock art images seems to be typical of this medium. Contemporary Late Bronze Age razors share similar imagery, ie ships and animals. Here the maker was restricted by the small size of these objects, which are typically less than $10 \mathrm{~cm}$ long (Kaul 1998). However, even though space was limited, there are no examples of incomplete images. Instead, the craftsperson used various techniques to squeeze the images onto the small space available (Fig. 5); leaving an image unfinished was never a way to solve the problem of restricted space (Sørensen \& Appleby 2018). In contrast to rock art, engravings on metal are a predominantly visual medium dependent on displaying complete objects for the sake of (visual) clarity.

The different ways of treating images on rock art panels and on metalwork could be related to the two different formats: a visual-tactile format (rock art) with a focus on pertinent pieces of information rather than a complete whole in order to characterise a certain thing, and a visual format (decorated metalwork) where it was important to display complete objects for the sake of clarity. The makers might have also been relying on basic human cognitive operations for making sense of the world, in this case, chiefly through indexical and iconic reasoning and understanding.

We have discussed a number of features in the southern Scandinavian rock art tradition which could explain how touch may have been used in combination with sight in order to comprehend the images: the small size of the images, the use of tactile markers, the occurrence of unfinished images, and the orthographic perspective. However, we do not expect the use of touch to be the only explanation for these phenomena. Cognitive processes and design cannot be detached from their sociocultural environment; practical, aesthetic, and ritual aspects may have triggered similar processes as those we have discussed from a purely cognitive perspective. For example, orthographic perspective is not only useful tactilely, it also has many visual advantages, and the importance of depicting all 
parts of an object could have also been influenced by the ritual and social significance of certain objects. In the Nordic Bronze Age, the spoked wheels attached to chariots were masterpieces of handicraft and had great sociocultural value (Kähler Holst \& Jensen 2015, 13-45); it would therefore make sense that they were designed so that all wheels were easily recognisable. A similar argument could be made concerning the previously discussed upward pointed phalluses, which may have signalled an important social identity in contemporary society. Fredrik Fahlander (2018) has discussed the exaggeration of certain details such as calves, phalluses, and swords in the Enköping area of eastern Sweden. In his view, this phenomenon could be explained by a wish to provoke certain reactions among the viewers, ie to create an interest and further engagement with these specific images. Similar processes might also help to explain the occurrence of unfinished images (Fahlander 2018, 77-82), which could have resulted from the engraving process being interrupted, preventing the maker from completing the image.

We would argue sociocultural aspects work in tandem with cognitive processes. Unfinished images, whether intentionally created or as a result of interrupted production, may not have posed a problem when interpreted tactilely. The exaggeration of certain features previously discussed may have had a sociocultural significance, but their wider spread and use might have been facilitated by their usefulness in a tactile mode. Indeed, it makes sense that the socioculturally important features were those that were exaggerated in order to achieve tactile recognition; the two processes are intertwined, and it is difficult to separate them analytically.

The tactile perspective put forward offers complementary perspectives on certain features in the southern Scandinavian rock art that hitherto have not been discussed from a cognitive perspective. It has the advantage of contextualising different kinds of observations in relation to a cognitive framework, where touch and not only sight, was important.

\section{CONCLUDING WORDS}

Rock art can be experienced through a variety of senses, but the scientific discussion tends to focus on sight, even though other aspects such as touch (eg, Ouzman 2001; Lahelma 2010) and sound (eg, Goldhahn 2002; Lahelma 2010) were likely part of the original experience. This is a result of experiencing this rock art in another sociocultural context (our present day), where the context-dependent factors of the original semiotic structure have changed (Rédei 2007; Hamilakis 2013; Rédei et al. 2019). This has made the rock art less place-specific and has triggered new understandings of the relationship between its tactile and visual qualities, in which the tactile dimension has been less of a focus.

We suggest that southern Scandinavian rock art images fall on a continuum between touch-dependent and purely visual images. In the tactile extreme, we can expect some effects that are difficult to explain from a purely visual standpoint, as described above. Furthermore, pictures that depend heavily on touch pose limitations for both the creative and narrative content that can be ascribed to them.

Following Hopkins (2000), for almost exclusively tactile images, one cannot assume that the artistic intent of the carver is automatically transferred to the perceiver, who needs to construct the image through a sense that mentally imagines wholes from parts. Consequently, from the makers' perspective, he or she does not need to put effort into making the most elaborated image, but rather the most interpretable one. This can explain the simplicity of many images, while the skill and motivation for more complicated displays is clearly present in other images. These, we propose, fall on the visual side of the spectrum.

In addition, the particularities that we attribute throughout this paper to the tactile format would affect how the images were comprehended when using rock art to communicate stories or narratives. Using the tactile sense to interpret the images would create fragmented pieces of information caused by a time-consuming interaction with the rock art surface very different from face-to-face communication. When interpreting the signs, the qualities of the rock, together with factors like sight, touch, and body movement, would create a slow and piecemeal communicative process, where pieces of information create wholes that are heavily dependent on the expectations of the interpreter. This makes it nearly impossible to convey events through the rock art medium that are not already well known by the person exploring the pictures (Ranta et al. 2019). With visual help, however, the multisensory picture is freed from these limitations and more detail can be included. We argue that creativity and storytelling in rock art can thus be a direct consequence of the quality of the rock itself, and 


\section{P. Skoglund et al. A MULTISENSORY APPROACH TO SOUTHERN SCANDINAVIAN ROCK ART}

that when conceptualising rock art, one must include the sense modalities - ie human perception - in the analysis.

We suggest that it is possible to place rock art images on a scale of visual predominance, where some are multimodal, and others are exclusively visual. We do not expect a clear division between sites, however, since it is plausible that reliance on the purely visual dimension has varied across time, depending on how often panels were revisited, the particular rock properties, and whether the placement of the images allowed exploration by touch. Of course, design choices originally motivated by the tactile dimension can also be interpreted as part of a style of purely visually motivated images. Our theory thus has a weak predictive power, but it could explain several phenomena in rock art that are confusing from a purely visual perspective.

Acknowledgements: This article was written as part of the project StoRock (Storytelling in Rock Art), financed by the Swedish Research Council [Grant nr. 2016-01288], to which we hereby would like to express our gratitude. Thanks to Courtney Nimura for helping us prepare the final text.

\section{REFERENCES}

Bakkevig, S. 2004. Rock art preservation: Improved and ecology-based methods can give weathered sites prolonged life. Norwegian Archaeological Review 37(2), 65-81

Bengtsson, L. 2002. Att gräva ut hällbilder. In J. Goldhahn (ed.), Bilder av bronsallder: ett seminarium om förhistorisk kommunikation: rapport frän ett seminarium på Vitlycke museum 19.e-22.e oktober 2000, 261-81. Stockholm: Almqvist \& Wiksell

Classen, C. 2012. The Deepest Sense: A cultural history of touch. Urbana, IL: University of Illinois Press

Coles, J. 2006. Beacon on the Ridge: Rock carvings at Kasen Lövåsen Bohuslän, Sweden. Proceedings of the Prehistoric Society 72, 319-39

Crumlin-Pedersen, O. \& Trakadas, A. (eds). 2003. Hjortspring: A Pre-Roman Iron-Age warship in context. Roskilde: Viking Ship Museum

Day, J. (ed.) 2013. Making Senses of the Past: Toward a sensory archaeology. Carbondale, IL: Center for Archaeological Investigations, Southern Illinois University Carbondale \& Southern Illinois University Press

Eriksson, Y. 1998. Tactile Pictures: Pictorial representations for the blind 1784-1940. Gothenburg: Gothenburg University
Fahlander, F. 2012. Articulating stone: The material practice of petroglyphing. In I.-M. Back Danielsson, F. Fahlander \& Y. Sjöstrand (eds), Encountering Imagery: Materialities, perceptions, relations, 97-116. Stockholm: Stockholm University

Fahlander, F. 2013. Articulating relations: A nonrepresentational view of Scandinavian rock art. In B. Alberti, A.M. Jones \& J. Pollard (eds), Archaeology after Interpretation: Returning materials to archaeological theory, 305-24. Walnut Creek, CA: Left Coast Press

Fahlander, F. 2018. Bildbruk i mellanrum: Mälarvikens hällbilder under andra årtusendet fvt. Stockholm: Institutionen för arkeologi och antikens kultur, Stockholm University

Fahlander, F. \& Kjellström, A. (eds). 2010. Making Sense of Things: Archaeologies of sensory perception. Stockholm: Stockholm University

Gjerde, J.M. 2010. Rock Art and Landscapes: Studies of Stone Age rock art from northern Fennoscandia. Tromsø: University of Tromsø

Goldhahn, J. 2002. Roaring rocks - an audio-visual perspective on hunter-gatherer engravings in Northern Sweden and Scandinavia. Norwegian Archaeological Review 35(1), 29-61

Goldhahn, J. 2012. In the wake of a voyager: Feet, boats and death rituals in the North European Bronze Age. In A.M. Jones, J. Pollard, M.J. Allen \& J. Gardiner (eds), Image, Memory and Monumentality: Archaeological engagements with the material world, 218-32. Oxford: Prehistoric Society Research Papers 5

Goldhahn, J. \& Ling, J. 2013. Bronze Age rock art in Northern Europe: Contexts and interpretations. In H. Fokkens \& A. Harding (eds), The Oxford Handbook of the European Bronze Age, 270-90. Oxford: Oxford University Press

Hamilakis, Y. 2013. Archaeology and the Senses: Human experience, memory, and affect. New York, NY: Cambridge University Press

Hauptman, K. 2002. Bilder av betydelse: hällristningar och bronsålderslandskap $i$ nordöstra Östergötland. Stockholm: Stockholm University

Hopkins, R. 2000. Touching pictures. British Journal of Aesthetics 40(1), 149-67

Horn, C. \& Potter, R. 2018. Transforming the rocks - time and rock art in Bohuslän, Sweden. European Journal of Archaeology 21(3), 361-84

Jones, A.M. 2015. Meeting pasts halfway: A consideration of the ontology of material evidence in archaeology. In R. Chapman \& A. Wylie (eds), Material Evidence: Learning from archaeological practice, 324-38. London: Routledge

Jones, A.M. Freedman, D. \& O'Connor, B. (eds). 2011. An Animate Landscape: Rock art and the prehistory of Kilmartin, Argyll, Scotland. Oxford: Windgather Press

Kahler Holst, M. \& Jensen, P. 2015. The idea of the barrow. In M. Kahler Holst \& M. Rasmussen (eds), Skelhøj and the Bronze Age Barrows of Southern Scandinavia. Vol. 2, 13-52. Højbjerg: Jutland Archaeological Society 
Karlsson, S. 2005. Kroppens gestaltning och symbolik på Sydskandinaviens hällristningar. In J. Goldhahn (ed.), Mellan sten och järn 2, 461-72. Gothenburg: Gothenburg University

Kaul, F. 1998. Ships on Bronzes: A study in Bronze Age religion and iconography. Copenhagen: National Museum

Kennedy, J.M. \& Ross, A.S. 1975. Outline picture perception by the Songe of Papua. Perception 4, 391-406

Kennedy J.M. \& Silver, J. 1974. The surrogate functions of lines in visual perception: Evidence from antipodal rock and cave artwork sources. Perception 3, 313-22

Lahelma, A. 2010. Hearing and touching rock art Finnish rock paintings and the non-visual. In J. Goldhahn, I. Fuglestvedt \& A. Jones (eds), Changing Pictures: Rock art traditions and visions in northernmost Europe, 48-59. Oxford: Oxbow Books

Ling, J. 2008. Elevated Rock Art: Towards a maritime understanding of Bronze Age rock art in northern Bohuslän, Sweden. Gothenburg: University of Gothenburg

Ling, J. 2013. Rock Art and Seascapes in Uppland. Oxford: Oxbow Books

Ljunge, M. 2015. Bortom avbilden: sydskandinaviska hällbilders materialitet. Stockholm: Stockholm University

Lopes, D.M.M. 1997. Art media and the sense modalities: Tactile pictures. Philosophical Quarterly 47(189), 425-40

Marstrander, S. 1963. Østfolds jordbruksristninger. Oslo: Oslo University

Milstreu, G. 2017. Re-cut rock art images (with a special emphasis on ship carvings). In S. Bergerbrant \& A. Wessman (eds), New Perspectives on the Bronze Age: Proceedings of the 13th Nordic Bronze Age Symposium held in Gothenburg 9th to 13th June 2015, 281-87. Oxford: Archaeopress

Nimura, C. 2016. Prehistoric Rock Art in Scandinavia: Agency and environmental change. Oxford: Oxbow Books

Ouzman, S. 2001. Seeing is Deceiving: Rock art and the non-visual. World Archaeology 33(2), 237-56

Palincaş, N. 2010. Reconfiguring anatomy: Ceramics, cremation and cosmology in the Late Bronze Age in the Lower Danube. In K. Rebay-Salisbury, M.L.S. Sørensen \& J. Hughes (eds), Body Parts and Bodies Whole: Changing relations and meanings, 72-89. Oxford: Oxbow Books

Peirce, C.S. 1998. The Essential Peirce, vol. 2. The Peirce Edition Project. Bloomington, ID: Indiana University Press
Pellini, J.R., Zarankin, A. \& Salerno, M.A. 2015. Coming to Senses: Topics in sensory archaeology. Newcastle upon Tyne: Cambridge Scholars Publishing

Ranta, M., Skoglund, P., Rédei, A.C. \& Persson, T. 2019. Levels of narrativity in Scandinavian Bronze Age petroglyphs. Cambridge Archaeological Journal 29(3), 497-516

Rédei, A.C. 2007. An Inquiry into Cultural Semiotics: The example of Germaine de Staël's autiobiographical travel accounts. Lund: Lund University

Rédei, A.C., Skoglund, P. \& Persson, T. 2019. Applying cartosemiotics to rock art: An example from Aspeberget, Sweden. Social Semiotics 29(4), 543-56

Rex Svensson, K. 1982. Hällristningar i Älvsborgs län: en inventering av samtliga kända hällristningar $i$ Dalsland och Göta älvdalen. Vänersborg: Älvsborgs länsmuseum

Skeates, R. 2010. An Archaeology of the Senses: Prehistoric Malta. Oxford: Oxford University Press

Skoglund, P., Nimura, C. \& Bradley, R. 2017. Interpretations of footprints in the Bronze Age rock art of south Scandinavia. Proceedings of the Prehistoric Society 83, 289-303

Skogstrand, L. 2005. Krigerrollen som et maskulint ideal i yngre bronsealder. In J. Goldhahn (ed.), Mellan sten och järn 2, 659-67. Gothenburg: Gothenburg University

Sonesson, G. 1994. Prolegomena to the semiotic analysis of prehistoric visual displays. Semiotica 100, 267-331

Sonesson, G. 2016. Human history as the continuation of evolution by (partially) other means. In D. Dunér \& G. Sonesson (eds), Human Lifeworlds: The cognitive semiotics of cultural evolution, 301-35. Bern: Peter Lang

Sørensen, M.L.S. \& Appleby, G. 2018. To decorate a Nordic Bronze Age razor: A design challenge. In L. Bender Jørgensen, J.R. Sofaer \& M.L.S. Sørensen (eds), Creativity in the Bronze Age: Understanding innovation in pottery, textile, and metalwork production, 191-206. Cambridge: Cambridge University Press

Tilley, C. 2004. The Materiality of Stone: Explorations in landscape phenomenology 1. Oxford: Berg

Vogt, D. 2006. Helleristninger $i$ Østfold og Bohuslän: en analyse av det økonomiske og politiske landskap. Oslo: Oslo University

Yates, T. 1993. Frameworks for an archaeology of the body. In C. Tilley (ed.), Interpretative Archaeology, 31-72. Oxford: Berg

\section{RÉSUMÉ}

Une approche multi sensorielle de l'art rupestre:exploration des dimensions tactiles et visuelles dans la tradition de l'art rupestre en Scandinavie du sud, de Peter Skoglund, Tomas Persson \& Anna Cabak Rédei

Cet article discute l'art rupestre de la Scandinavie du sud en tant que format multi sensoriel dans lequel à la fois la vue et le toucher auraient contribué à la compréhension des images. D'un point de vue sémiotique structurel, nous proposons que l'art rupestre peut s'interpréter comme un ensemble organisé de traits tel que des éléments tactiles et visuels organisés en unités hétérogènes avec des relations dynamiques entre les éléments qui peuvent changer au fil du temps en fonction de comment ils sont ressentis. Nous argumentons que pour comprendre le medium de l'art rupestre, il est crucial de tenir compte de l'interaction multi sensorielle entre celui qui perçoit et 


\section{P. Skoglund et al. A MULTISENSORY APPROACH TO SOUTHERN SCANDINAVIAN ROCK ART}

les qualités de la surface de l'art rupestre. La raison pour l'inclusion des éléments tactiles dans notre interprétation de la conception de l'art rupestre est la manière dont il a été créé: par des mains en interaction avec des outils et des surfaces de roches, aussi bien que par la tendance humaine spontanée à explorer le monde physique à travers le toucher. On peut identifier des éléments clés dans les images qui potentiellement faciliteraient une reconnaissance tactile tout comme 'ils seraient mieux expliqués d'un point de vue multisensoriel Ceci comprend la position des images sur des affleurements rocheux horizontaux, la taille modérée des images, l'application d'une perspective orthographique,l'utilisation de `marqueurs tactiles`(c'est à dire de traits cruciaux ayant une fonction stratégique pour comprendre les images par le toucher), et l'occurence d'images incomplètes. Une perspective multi sensorielle de l'art rupestre a de plus des implications sémiotiques. Les images incomplètes, par exemple, peuvent être comprises comme des indices de remplacement pour le dessin entier imaginé, c'est à dire comme des indices iconiques Une approche multi sensorielle de l'art pariétal ascandinave nous permet donc de nouvelles explications pour certains choix de dessins ainsi qu'une nouvelle compréhension de comment les images pouvaient faire passer un message à celui qui les reperçoit.

\section{ZUSAMMENFASSUNG}

Eine multisensorische Untersuchung von Felsbildern: Die Erforschung von taktilen und visuellen Dimensionen in der Felsbildkunst Südskandinaviens, von Peter Skoglund, Tomas Persson und Anna Cabak Rédei

Dieser Beitrag erörtert die Felsbildkunst in Südskandinavien als ein multisensorisches Format, bei dem sowohl Ansicht als auch Berührung zum Begreifen der Bilder beigetragen haben. Von einem struktursemiotischen Standpunkt aus schlagen wir vor, dass Felsbilder als organisierter Satz von Merkmalen interpretiert werden können, wie z.B. visuelle und taktile Elemente, die in heterogenen Einheiten organisiert waren mit dynamischen Beziehungen zwischen Elementen, die sich in Bezug auf ihre Erfahrbarkeit im Verlauf der Zeit ändern können. Wir argumentieren, dass es für ein Verständnis von Felsbildern als Medium zwingend notwendig ist die multisensorische Interaktion zwischen dem Wahrnehmenden und den Qualitäten der Felsoberfläche zu berücksichtigen. Der Grund, warum wir taktile Elemente in unsere Deutung der Wahrnehmung von Felsbildern einbeziehen, ist die Weise, in der sie erschaffen wurden: durch Hände, die mit Werkzeugen und Felsoberflächen interagieren, aber auch aufgrund der spontanen menschlichen Tendenz die physische Welt durch Berührung zu erkunden. Man kann Schlüsselmerkmale in den Bildern identifizieren, die möglicherweise das taktile Erkennen erleichtern würden und die zugleich besser aus einer multisensorischen Perspektive zu erklären sind. Dies schließt die Lage der Bilder auf horizontal ausgerichteten Felsen ebenso ein wie die bescheidene Größe der Bilder, die Anwendung einer orthographischen Perspektive, die Nutzung „taktiler Marker“ (d.h. dass entscheidende Merkmale eine strategische Funktion haben, um Bilder durch Berührung zu verstehen) und das Auftreten unvollständiger Bilder. Eine multisensorische Sichtweise auf Felsbildkunst hat zudem semiotische Implikationen. Unvollständige Bilder können z.B. verstanden werden als indexikalische Stellvertreter für das gesamte imaginierte Bild, d.h. als ikonische Indizes. Ein multisensorischer Zugang zu skandinavischen Felsbildern ermöglicht also neue Erklärungen für bestimmte Entscheidungen bei der Gestaltung der Bilder sowie ein Verständnis dafür, wie die Bilder eine Bedeutung an einen Wahrnehmenden vermittelt haben können.

\section{RESUMEN}

Un acercamiento multisensorial al arte rupestre: exploración táctil y dimensiones visuales en la tradición de arte rupestre del sur de Escandinavia, por Peter Skoglund, Tomas Persson y Anna Cabak Rédei

Este artículo discute el arte rupestre en el sur de Escandinavia desde una perspectiva multisensorial, donde tanto la vista como el tacto habrían contribuido a la comprensión de las imágenes. Desde la perspectiva de la semiótica estructural, sugerimos que el arte rupestre puede ser analizado como una serie de rasgos, tanto elementos visuales como táctiles, organizados en unidades heterogéneas mediante relaciones dinámicas entre ellos que pueden modificarse a lo largo del tiempo en función de cómo se han experimentado. Sostenemos que, para comprender 
el medio del arte rupestre, es crucial considerar la interacción multisensorial entre el receptor y las cualidades de la superficie del arte rupestre. La razón fundamental para incluir los elementos táctiles en nuestra interpretación de la concepción del arte rupestre es debido al modo en el que fue realizado: con las manos interactuando con las herramientas y las superficies de las rocas, así como la tendencia humana espontánea de explorar el mundo físico a través del tacto. Se pueden identificar rasgos clave en las imágenes que podrían facilitar el reconocimiento táctil, al igual que una mejor explicación desde la perspectiva multisensorial. Esto incluye la posición de las imágenes en los afloramientos horizontales, el moderado tamaño de las imágenes, la aplicación de una perspectiva ortográfica, el uso de los “marcadores táctiles" (por ejemplo, rasgos cruciales que tengan una función estratégica para la comprensión táctil de las imágenes) y la existencia de imágenes incompletas. La perspectiva multisensorial en arte rupestre tiene igualmente implicaciones semióticas. Las imágenes incompletas, por ejemplo, pueden entenderse como reemplazos de la imagen completa, es decir, como relaciones icónicas. Esta aproximación multisensorial al arte rupestre escandinavo nos permite, por tanto, proponer nuevas explicaciones para ciertos diseños, así como una nueva comprensión de cómo las imágenes pueden trasmitir un significado a una receptor. 